\title{
Measures of chronic heart failure as the markers of cognitive dysfunction in patients with coronary heart disease complicated by circulatory failure
}

\author{
Natalya S. Akimova, Oksana V. Bugaeva, Larisa E. Konshina, Yury G. Shvarts
}

V. I. Razumovsky Saratov SMU MOH, Russia

\section{ARTICLE INFO}

Article history:

Submitted: 24. 7. 2020

Revised: 21. 9. 2020

Accepted: 26. 10. 2020

Available online: 5. 2. 2021

\section{Klíčová slova:}

Difuzní koeficient molekul vody

Chronické srdeční selhání

Ischemická choroba srdeční

Kognitivní dysfunkce

Tloušt'ka šedé hmoty
SOUHRN

Cíl: Zkoumat vztah mezi morfologickými a funkčními změnami mozku versus ejekční frakcí levé komory a funkční třídou chronického srdečního selhání.

Materiál a metody: U 54 pacientů s chronickým srdečním selháním třídy II-IV ischemické etiologie byly provedeny kognitivní testy, echokardiografické vyšetření a vyšetření mozku nukleární magnetickou rezonancí. Výsledky: Se zvyšující se funkční třídou chronického srdečního selhání Ize pozorovat nižší kognitivní skóre V a VII podle Wechslerovy škály, řidší šedou hmotu v parietálním laloku, menší objem hipokampu, nižší difuzní koeficient molekul vody v šedé hmotě parietální a okcipitální oblasti a menší šířku dolních stopek středního mozku. Srovnávací analýza parametrủ centrální nervové soustavy u pacientů s chronickým srdečním selháním a různými hodnotami ejekční frakce levé komory neprokázala statisticky významné rozdíly. Závěr: Naše výsledky potvrzují význam funkční třídy chronického srdečního selhání jako ukazatele kognitivní dysfunkce a patologických změn v šedé i bílé hmotě, zatímco ejekční frakce levé komory je zjevně méně užitečným parametrem.

(C) 2021, ČKS
Keywords:

Chronic heart failure

Cognitive dysfunction

Coronary heart disease

Diffusion coefficient of the water

molecules

Gray matter thickness

\section{ABSTRACT}

Objective: To study the relationship between the cerebral morpho-functional changes and left ventricular ejection fraction and functional class of chronic heart failure.

Materials and methods: The cognitive tests, echocardiography, and brain nuclear magnetic resonance imaging were performed in 54 patients with class II-IV chronic heart failure of ischemic origin.

Results: While the functional class of chronic heart failure is increased, lower Wechsler V and VII cognitive scores, thinner parietal gray matter, smaller hippocampal volume, lower diffusion coefficient of the water molecules in the parietal and occipital white matter, and lower middle cerebellar peduncle width are observed. The comparative analysis of the central nervous system parameters in patients with chronic heart failure with various left ventricular ejection fraction revealed no significant differences.

Conclusion: The results confirm the significance of the chronic heart failure functional class to be as a marker of cognitive dysfunction and pathological changes both in gray and white matter, while left ventricular ejection fraction is clearly less useful. 


\section{Introducion}

The increasing number of investigators pays their attention to extracardiac disorders, including central nervous system (CNS) disorders, in patients with cardiovascular diseases (CVD). These extracardiac CNS disorders include the development or aggravation of existing cognitive dysfunction. ${ }^{1-6}$

Our previous studies demonstrated the significant correlation between the severity of chronic heart failure (CHF) and functional (cognitive functions) and morphological (temporal, parietal, and occipital gray matter thickness, middle cerebellar peduncle width, and diffusion of the water molecules) status of the central nervous system. ${ }^{7-9}$

In modern cardiology, functional class (FC) and left ventricular ejection fraction (LVEF) are the most commonly used parameters to determine the severity of $\mathrm{CHF}^{3-5,10}$ Generally, while LVEF is decreased, FC is increased, but the correlation between FC and LVEF is not clearly defined. Typically, the patients with low ejection fraction $(<35 \%)$ report no significant CHF symptom, while some patients with heart failure characterized with relatively preserved systolic function (LVEF $\geq 45 \%$ ) have FC III or even FC IV.

\section{The objective of the study}

To investigate the comparative relationships between the cerebral functional and morphological changes and factors most commonly used to determine the severity of CHF: LVEF and FC.

\section{Materials and methods}

The study was conducted in accordance with the Good Clinical Practice principles and was approved by the Local Ethics Committee. The inclusion criteria were as follows: CHF developed on the background of confirmed coronary heart disease (CHD); age $\leq 65$ years old; use of angiotensin-converting enzyme inhibitors or angiotensin receptor blockers and beta-blockers at a stable dose for four weeks before enrollment. The patients who had acute or subacute CHD; diabetes mellitus; cerebrovascular accident (including in history); atherosclerotic plaques in the arteries of the head and neck with hemodynamicaIly significant stenoses (narrowing $>50 \%$ of the arterial lumen) by duplex ultrasound; dementia according to $\mathrm{Mi}$ ni-Mental Score Examination (MMSE) score; myocarditis; thyroid dysfunctions; severe valvular defects, laboratory results reflecting severe liver and kidney dysfunction; other somatic disorders that, in investigator's opinion, can be an independent cause of cognitive disorders; and contraindications to nuclear magnetic resonance imaging (NMRI); abused alcohol; administrated neurometabolic and/or neurotrophic agents and any other substances that directly or indirectly affect cognitive function, within 90 days before enrollment were excluded from the study. History data and clinical examination results were entered in the formalized medical history. If a patient had decompensated CHF, he/she was included in the study 1
Table 1 - Primary clinical characteristics of the examined

patients (median and quartiles)

\begin{tabular}{|l|l|}
\hline Parameter & $\begin{array}{l}\text { Patients with chronic } \\
\text { heart failure }(\mathrm{n}=54)\end{array}$ \\
\hline Age, years & $58.08(53-63)$ \\
\hline Males, $\mathrm{n}(\%)$ & $31(58)$ \\
\hline Height, cm & $171(160.5-174.5)$ \\
\hline Body weight, kg & $84.8(74.5-95.5)$ \\
\hline Left ventricular ejection fraction, \% & $48,5 \pm 16,7$ \\
\hline Patients with ejection fraction <45\%, \% & 48.2 \\
\hline Patients with functional class III-IV, \% & 43.7 \\
\hline Previous myocardial infarction, $\mathrm{n}(\%)$ & $30(55.4)$ \\
\hline Arterial hypertension, $\mathrm{n}$ (\%) & $48(88.3)$ \\
\hline Coronary heart disease duration, months & $60.1(35.7-86.1)$ \\
\hline Chronic heart failure duration, months & $46.2(20.6-68.7)$ \\
\hline
\end{tabular}

month after stabilization. All study tests were performed in the mornings when the informed consent was signed. Totally, 54 patients were enrolled. The primary clinical characteristics of the examined patients are presented in Table 1.

In addition to the common clinical laboratory tests, standard electrocardiography (ECG) and echocardiography were performed, and the following primary parameters were taken into account: left atrial end-systolic dimension (LAESD), left ventricular end-diastolic dimension (LVEDD), and right ventricular end-diastolic dimension (RVEDD). In some cases, cycle ergometer and 24-hour Holter monitoring were used to verify CHD. To assess the CNS morphology, NMRI of the brain was used. NMRI was performed using Philips Achieva 1.5 T device. The gray matter (GM) thickness in the occipital, frontal, parietal and temporal lobes, as well as volume of the right and left hippocampus - parts of the limbic system involved in formation of emotion and memory consolidation, were measured. To investigate the white matter (WM), the middle cerebellar peduncle width was determined. In addition to the standard diffusion-weighted brain NMRI, the diffusion coefficient (DC) of the water molecules in the gray and white matter of the occipital, frontal, parietal, temporal lobes and hippocampus were calculated. The cognitive functions were assessed via Wechsler Verbal and Nonverbal Scale of Ability (V and VII subtests) and Bourdon test (Dot Cancellation Test). To exclude dementia, the Mini-Mental State Examination (MMSE) scale a brief scale assessing mental status, was used.

\section{Statistical analysis}

Categorical variables were summarized using frequencies (\%). The mean \pm standard deviation was used for continuous variables. The independent samples t-test was used for continuous variables. Categorical variables were compared using the chi-squared test or Fisher's exact test, as appropriate. The relationship between the functional and morphological changes in the brain and LVEF and CHF FC were analyzed using nonparametric correlation (Kendall test) and canonical analyses. A $p$-value $<0.05$ was taken as 
Table 2 - Cognitive measures and nuclear magnetic resonance imaging parameters of the brain in patients with FC II and FC III-IV (median and quartiles)

\begin{tabular}{|c|c|c|c|}
\hline Parameter & FC II $(n=30)$ & FC III-IV ( $(n=24)$ & Significance level ( $p$ ) \\
\hline Age, years & 54.4 & 54.6 & 0.85 \\
\hline Wechsler V, scores & $10.75(10.91-12.59)$ & $9.09(8.06-11.94)$ & 0.04 \\
\hline Wechsler VII, scores & $39.83(42.71-44.66)$ & $32.78(27.07-37.93)$ & 0.03 \\
\hline Bourdon test (vigilance), units & $0.89(0.87-0.93)$ & $0.83(0.64-1.02)$ & 0.08 \\
\hline Bourdon test (time spent), characters per minute & $115.63(106.86-124.40)$ & $111.82(102.50-121.14)$ & 0.60 \\
\hline Frontal gray matter thickness, $\mathrm{mm}$ & $4(3.5-4)$ & $3.5(3.5-4.5)$ & 0.51 \\
\hline Parietal gray matter thickness, $\mathrm{mm}$ & $3.5(3.5-4)$ & $3(3-3.8)$ & 0.02 \\
\hline Occipital gray matter thickness, $\mathrm{mm}$ & $3.5(3-4)$ & $3(3-3.5)$ & 0.43 \\
\hline Temporal gray matter thickness, $\mathrm{mm}$ & $4(4-4.5)$ & $4(3.75-4)$ & 0.71 \\
\hline Right hippocampal volume, $\mathrm{cm}^{3}$ & $5.54(4.30-6.40)$ & $4.26(3.71-4.87)$ & 0.02 \\
\hline Left hippocampal volume, $\mathrm{cm}^{3}$ & $5.02(4.25-5.81)$ & $4.38(4.03-5.26)$ & 0.09 \\
\hline Diffusion coefficient in the frontal gray matter, $\mathrm{m}^{2} / \mathrm{s}$ & $0.44(0.39-0.45)$ & $0.39(0.35-0.4)$ & 0.2 \\
\hline Diffusion coefficient in the parietal gray matter, $\mathrm{m}^{2} / \mathrm{s}$ & $0.44(0.4-0.46)$ & $0.43(0.35-0.47)$ & 0.71 \\
\hline Diffusion coefficient in the occipital gray matter, $\mathrm{m}^{2} / \mathrm{s}$ & $0.47(0.41-0.49)$ & $0.44(0.38-0.45)$ & 0.26 \\
\hline Diffusion coefficient in the temporal gray matter, $\mathrm{m}^{2} / \mathrm{s}$ & $0.45(0.41-0.46)$ & $0.43(0.4-0.46)$ & 0.77 \\
\hline $\begin{array}{l}\text { Diffusion coefficient in the right hippocampal } \\
\text { gray matter, } \mathrm{m}^{2} / \mathrm{s}\end{array}$ & $0.37(0.34-0.41)$ & $0.34(0.31-0.37)$ & 0.11 \\
\hline $\begin{array}{l}\text { Diffusion coefficient in the left hippocampal } \\
\text { gray matter, } \mathrm{m}^{2} / \mathrm{s}\end{array}$ & $0.37(0.35-0.41)$ & $0.33(0.29-0.36)$ & 0.08 \\
\hline
\end{tabular}

Table 3 - Cognitive measures and nuclear magnetic resonance imaging parameters of the brain in patients with left ventricular ejection fraction $>45 \%$ or $<45 \%$ (median and quartiles)

\begin{tabular}{|c|c|c|c|}
\hline Parameter & $\begin{array}{l}\text { Patients with LV EF } \geq 45 \% \\
(n=28)\end{array}$ & $\begin{array}{l}\text { Patients with LV EF }<45 \% \\
(n=26)\end{array}$ & $\begin{array}{l}\text { Significance level } \\
\text { (p) }\end{array}$ \\
\hline Age & 54.4 & 54.6 & 0.94 \\
\hline Wechsler 5, scores & $10.02(9-12)$ & $9.54(8-11)$ & 0.36 \\
\hline Wechsler 7, scores & $38.5(32-47)$ & $34(24-41)$ & 0.74 \\
\hline Bourdon test (vigilance), units & $0.87(0.84-0.93)$ & $0.87(0.81-0.94)$ & 0.22 \\
\hline Bourdon test (time spent), characters per minute & $113.5(112-125)$ & $108(102-126)$ & 0.14 \\
\hline Bourdon test (accuracy), units & $1.8(1.25-2.6)$ & $1.6(0.97-3.6)$ & 0.46 \\
\hline Frontal gray matter thickness, mm & $4(3.5-4.5)$ & $3.5(3.5-4.7)$ & 0.24 \\
\hline Parietal gray matter thickness, $\mathrm{mm}$ & $3.5(3.5-4)$ & $3.5(3-4)$ & 0.52 \\
\hline Occipital gray matter thickness, $\mathrm{mm}$ & $3.5(3-4)$ & $3(3-3.5)$ & 0.43 \\
\hline Temporal gray matter thickness, $\mathrm{mm}$ & $4(4-5)$ & $4(4-4.5)$ & 0.41 \\
\hline Right hippocampal volume, $\mathrm{mm}^{3}$ & $4.71(4.02-5.51)$ & $4.65(3.93-5.14)$ & 0.88 \\
\hline Left hippocampal volume, $\mathrm{mm}^{3}$ & $4.58(4.04-5.26)$ & $4.57(3.41-5.37)$ & 0.98 \\
\hline Diffusion coefficient in the frontal gray matter, $\mathrm{m}^{2} / \mathrm{s}$ & $0.4(0.35-0.45)$ & $0.44(0.37-0.48)$ & 0.23 \\
\hline Diffusion coefficient in the parietal gray matter, $\mathrm{m}^{2} / \mathrm{s}$ & $0.42(0.37-0.47)$ & $0.43(0.37-0.46)$ & 0.71 \\
\hline Diffusion coefficient in the occipital gray matter, $\mathrm{m}^{2} / \mathrm{s}$ & $0.44(0.41-0.49)$ & $0.44(0.38-0.49)$ & 0.29 \\
\hline Diffusion coefficient in the temporal gray matter, $\mathrm{m}^{2} / \mathrm{s}$ & $0.42(0.39-0.46)$ & $0.43(0.4-0.47)$ & 0.87 \\
\hline $\begin{array}{l}\text { Diffusion coefficient in the right hippocampal } \\
\text { gray matter, } \mathrm{m}^{2} / \mathrm{s}\end{array}$ & $0.37(0.32-0.41)$ & $0.34(0.31-0.38)$ & 0.25 \\
\hline $\begin{array}{l}\text { Diffusion coefficient in the left hippocampal } \\
\text { gray matter, } \mathrm{m}^{2} / \mathrm{s}\end{array}$ & $0.35(0.33-0.38)$ & $0.35(0.32-0.39)$ & 0.92 \\
\hline
\end{tabular}


Table 4 - Middle cerebellar peduncle width and diffusion coefficient of the water molecules in the white matter in patients with FC II and FC III-IV (median and quartiles)

\begin{tabular}{|l|l|l|l|}
\hline Parameter & FC II $(\mathbf{n = 3 0})$ & FC III-IV $(\mathbf{n}=24)$ & Significance level $(\boldsymbol{p})$ \\
\hline Middle cerebellar peduncle width, $\mathrm{mm}$ & $13(12-14)$ & $11.5(12-14)$ & 0.04 \\
\hline Frontal water molecules diffusion coefficient, $\mathrm{m}^{2} / \mathrm{s}$ & $0.45(0.41-0.47)$ & $0.40(0.35-0.46)$ & 0.11 \\
\hline Parietal water molecules diffusion coefficient, $\mathrm{m}^{2} / \mathrm{s}$ & $0.43(0.35-0.46)$ & $0.38(0.28-0.44)$ & 0.02 \\
\hline Occipital water molecules diffusion coefficient, $\mathrm{m}^{2} / \mathrm{s}$ & $0.43(0.41-0.45)$ & $0.37(0.31-0.43)$ & 0.04 \\
\hline Temporal water molecules diffusion coefficient, $\mathrm{m}^{2} / \mathrm{s}$ & $0.42(0.40-0.47)$ & $0.38(0.30-0.44)$ & 0.06 \\
\hline
\end{tabular}

Table 5 - Middle cerebellar peduncle width and diffusion coefficient of the water molecules in the white matter in patients with CHF depending on left ventricular ejection fraction value (median and quartiles)

\begin{tabular}{|l|l|l|l|}
\hline Parameter & $\begin{array}{l}\text { Ejection fraction } \geq \mathbf{4 5 \%} \\
(\mathbf{n = 2 8})\end{array}$ & $\begin{array}{l}\text { Ejection fraction <45\% } \\
(\mathbf{n = 2 6 )}\end{array}$ & Significance level (p) \\
\hline Middle cerebellar peduncle width, $\mathrm{mm}$ & $13(12-14)$ & $13(11-14)$ & 0.23 \\
\hline Diffusion coefficient in the frontal white matter, $\mathrm{m}^{2} / \mathrm{s}$ & $0.44(0.37-0.45)$ & $0.47(0.31-0.51)$ & 0.29 \\
\hline Diffusion coefficient in the parietal white matter, $\mathrm{m}^{2} / \mathrm{s}$ & $0.42(0.32-0.46)$ & $0.43(0.34-0.45)$ & 0.34 \\
\hline Diffusion coefficient in the occipital white matter, $\mathrm{m}^{2} / \mathrm{s}$ & $0.43(0.33-0.45)$ & $0.43(0.37-0.46)$ & 0.46 \\
\hline Diffusion coefficient in the temporal white matter, $\mathrm{m}^{2} / \mathrm{s}$ & $0.41(0.36-0.44)$ & $0.43(0.35-0.47)$ & 0.28 \\
\hline
\end{tabular}

an indicator of statistical significance. A statistical analysis was carried out using the Statistica, Version 8.0.

\section{Results}

We calculated the mean cognitive scores and NMRI parameters of the gray matter separately for patients with FC II and FC III-IV. The results are presented in Table 2.

As shown in Table 2, the patients with FC III-IV have significantly lower Wechsler V and VII scores. Moreover, the patients with FC III-IV have thinner parietal gray matter. The results confirm the significance of FC for the severity of caused extracardial systemic disorders.

The comparative analysis of changes in CNS parameters in patients with $\mathrm{CHF}$ characterized with relatively preserved systolic function ( $E F \geq 45 \%$ ) and in patients with CHF with reduced systolic function, revealed no significant differences (Table 3).

The similar results were obtained when the significance of differences between cognitive scores and brain NMRI parameters in patients with heart failure with EF $\leq 35 \%$ and $\mathrm{EF}>35 \%$ were evaluated.

The medians and quartiles of the middle cerebellar peduncle width and diffusion coefficient of the water molecules in the white matter were calculated separately for patients with FC II and FC III-IV. A number of significant differences were observed. The results and significance of differences between patients with FC II and FC III-IV are presented in Table 4.

In patients with FC III-IV, lower diffusion coefficient of the water molecules in the parietal and occipital white matter and lower middle cerebellar peduncle width were found.

Additionally, we performed a comparative analysis of the middle cerebellar peduncle width and diffusion coefficient of the water molecules in the white matter in patients with LVEF $\geq 45 \%$ and in patients with LVEF $<45 \%$, but no significant differences between these groups were noted (Table 5).

Moreover, the parameters characterizing the white matter were not significantly differed in CHF patients with $\mathrm{EF} \leq 35 \%$ and $\mathrm{EF}>35 \%$.

The results confirm the significance of the CHF functional class to be as a potential sign of more severe cognitive dysfunction and pathological brain changes both in gray and white matter, while left ventricular ejection fraction is clearly less useful.

\section{Discussion}

According to our data, the higher functional class of $\mathrm{CHF}$ corresponded to the worse results of cognitive tests. The influence of CHF on the "substrate" of intelligence, may be clarified analyzing the relationship between the severity of CHF and the status of the gray matter. Our patients with higher CHF FC had smaller thickness of the parietal gray matter.

It seems logical to explain that a more pronounced CHF corresponds with a more severe violation (deterioration) of the cerebral blood flow, probably, leading to the subsequent atrophy of the cerebral cortex. The latter obviously plays an important role in reducing the cognitive abilities. To some extent, our results are similar to the data obtained by Mary A. Woo, who described decreased volume of temporal gray matter and basal nuclei while CHF is progressed. ${ }^{11}$ Given the correlation between $\mathrm{CHF}$ FC and the status of the parietal lobes and, to some extent, occipital lobes, it is possible to assume that these lobes are the most "sensitive" to the deterioration of gray matter perfusion caused by CHF. Obviously, this issue should be investigated.

The observed decrease in the middle cerebellar peduncle width associated with increasing severity of CHF, 
may indicate some white matter atrophy mediated by CHF. It is possible that this atrophy associated with decreased number of nerve fibers and an increase in interfiber spaces improves the diffusion of water molecules in these spaces and increases the molecular velocity. In addition, hypoperfusion affects the integrity of the bloodbrain barrier, causes extravasation of plasma components into the vascular wall and adjacent areas of the brain accompanied with perivascular edema and activation of microglia. ${ }^{3,12}$ Moreover, the patients with CHF may have perivascular vasogenic edema due to impaired intracranial venous outflow in case of right ventricular heart failure and consistently progressive hyperactivation of the reninangiotensin-aldosterone system which leads, among others, to increased vascular permeability. 3,12,13

In addition, elevated thrombin/antithrombin complex, beta-tromboglobulin, and D-dimer levels are detected in patients with CHF, which contributes to the hypercoagulation ${ }^{14}$ and suggests a possible role of cerebral microembolism in the development of cognitive dysfunction. ${ }^{15}$

Therefore, perivascular white matter edema and hypercoagulation may be important factors for white matter pathology in case of cerebral microangiopathy which develops in CHF. It is reasonable to conduct more extensive trials, including morphological ones, to clarify the results of this study.

Since the patients with reduced and moderate/preserved LVEF were not significantly differed in the functional and morphological changes in the brain, it can be concluded that the clinical signs of CHF and its severity are more reliable markers of cognitive impairment and structural changes in the central nervous system in patients with coronary heart disease compared to instrumental evaluation of systolic heart dysfunction.

\section{Study limitations}

It should be noted that in this work we have analyzed data from a relatively small number of patients, and therefore it is necessary to perform a larger study.

\section{Conclusion}

The results demonstrate that LVEF, with all its important prognostic value, is a parameter reflecting systolic dysfunction, and does not always accurately correlate with the severity of heart failure. Probably, FC can serve as a more accurate measure of cognitive dysfunction and cerebral pathological changes. Perhaps, this is due to the fact that FC, along with assessing the clinical severity of $\mathrm{CHF}$, allows to evaluate, to some extent, the degree of its compensation. The sufficiency of CHF compensation mechanisms plays a significant role in the severity of its clinical manifestations, including the influence on the central nervous system. In particular, the circulatory failure caused by decreased LVEF can be compensated, to a certain extent, by the various local (autoregulation of cerebral blood flow) and common (metabolic adaptation and others) mechanisms. In this case, FC reflects more accurately the degree of such compensation and clearly characterizes not only physical capacity but also (indirectly) cognitive ability.

\section{Conflict of interest}

The authors declare no conflict of interest.

\section{Funding}

None.

\section{Ethical statement}

All procedures performed in studies involving human participants were in accordance with the ethical standards of the institutional and/or national research committee and with the 1964 Helsinki declaration and its later amendments or comparable ethical standards.

\section{Informed consent}

The patient's consent has been obtained.

\section{References}

1. Suzuki H, Matsumoto $\mathrm{Y}$, Ota $\mathrm{H}$, et al. Hippocampal Blood Flow Abnormality Associated With Depressive Symptoms and Cognitive Impairment in Patients With Chronic Heart Failure. Circ J 2016;8:1773-1780.

2. Niizeki T, Iwayama $T$, Ikeno $E$, et al. Prognostic Importance of Hippocampal Atrophy in Patients With Chronic Heart Failure. Am J Cardiol 2019;123:1109-1113.

3. Almeida OP, Flicker L. The mind of a failing heart: a systematic review of the association between congestive heart failure and cognitive functioning. Intern Med J 2001;31:290-295.

4. Caplan LR. Cardiac encephalopathy and congestive heart failure: a hypothesis about the relationship. Neurology 2006;66:99-101.

5. Suzuki $H$, Matsumoto $\mathrm{Y}, \mathrm{Ota} H$, et al. Interactions between the heart and the brain in heart failure patients assessed by magnetic resonance imaging - interim results from Brain assessment and investigation in Heart Failure Trial (B-HeFT). Eur Heart J 2013;34:2732.

6. Woo MA, Ogren JA, Abouzeid CM, et al. Regional hippocampal damage in heart failure. Eur J Heart Fail 2015;5:494-500.

7. Akimova NS, Persashvili DG, Shvarts YG, et al. Cognitive dysfunction and gray matter in patients with $\mathrm{CHF}$ and $\mathrm{CHD}$. Russ Heart Fail J 2011;67:282-285.

8. Akimova NS, Martynovich TV, Persashvili DG, et al. Relationship between the severity of chronic heart failure and white matter thickness, diffusion coefficient of the water molecules and cognitive functions. Fundamental Researches 2012;10:223-227.

9. Akimova NS, Bugaeva OV, Persashvili DG, et al. Characteristics of hippocampus, cognitive functions, lipid profile, and severity of chronic heart failure in patients with coronary heart disease. Cor Vasa 2020;62:29-32.

10. Ponikowsky PP, Adriaan AV, Stefan DA, et al. ESC Guidelines for the diagnosis and treatment of acute and chronic heart failure. Eur Heart J 2016;37:2129-2200.

11. Woo MA, Macey PM, Fonarow GC, et al. Regional brain gray matter loss in heart failure. J Appl Physiol 2003;2:677-684.

12. Bennet SJ, Sauve MJ. Cognitive deficits in patients with heart failure: a review of the literature. J Cardiovasc Nurs 2003;18:219-242.

13. Pozharskaya NI, Skvortsov. The role of neurohormonal systems in pathogenesis of chronic heart failure. Russ Med J 1999;7:1923.

14. Jafri SM, Ozawa T, Mammen E, et al. Platelet function, thrombin and fibrinolytic activity in patients with heart failure. Eur Heart J 1993;14:205-212.

15. Pullicino PM, Hart J. Cognitive impairment in congestive heart failure?: embolism vs hypoperfusion. Neurology 2001;57:19451946. 